\title{
KAJIAN PENGOBATAN HIPERTENSI DI PUSKESMAS KARANG ASAM SAMARINDA
}

\author{
Faisal Ramdani, Nur Mita, Rolan Rusli* \\ Laboratorium Penelitian dan Pengembangan Farmaka Tropis \\ Fakultas Farmasi Universitas Mulawarman, Samarinda Indonesia \\ *email: rolan@farmasi.unmul.ac.id
}

\begin{abstract}
ABSTRAK
Hipertensi merupakan penyakit kronis yang perlu diterapi dengan tepat dan terus menerus. Penelitian ini bertujuan untuk mengkaji pola pengobatan pada pasien hipertensi di Puskesmas Karang Asam Samarinda bulan Agustus tahun 2016. Penelitian ini bersifat deskriptif yang dilakukan secara prospektif terhadap resep obat kunjungan terakhir pasien. Pengambilan sampel 114 orang dilakukan secara purposive. Kategori usia pasien hipertensi terbanyak yaitu golongan lansia awal dengan rentang antara 45 sampai 55 tahun $(62,3 \%)$. Pola terapi obat antihipertensi terdiri atas terapi tunggal $(81,58 \%)$ dan kombinasi $(18,42 \%)$. Pada kelompok terapi tunggal terdapat 2 golongan obat yaitu Calcium Channel Blocker (CCB) yaitu Amlodipin (69,3\%) dan Angiotensin Converting Enzyme inhibitor (ACE-i) yaitu Captopril (12,3\%).
\end{abstract}

Kata kunci : Hipertensi, pola pengobatan, antihiperteni

\begin{abstract}
Hypertension is a chronic disease that needs to be treated promptly and continuously. This study aims to assess the treatment patterns in patients with hypertension in Puskesmas Karang Asam Samarinda in August 2016. This is a descriptive study conducted prospectively on prescription drugs last visit patients. Sampling was done by purposive 114 people. Most hypertensive patients age categories namely the elderly group beginning with a range between 45 to 55 years (62.3\%). The pattern of antihypertensive drug therapy consisted of monotherapy (81.58\%) and combination (18.42\%). In the single therapy group there are two classes of drugs are calcium channel blocker (CCB) namely Amlodipine (69.3\%) and Angiotensin Converting Enzyme inhibitors (ACE-I), namely Captopril (12.3\%).
\end{abstract}

Keywords: Hypertension, treatment patterns, antihypertensive

\section{PENDAHULUAN}

Hipertensi menjadi salah satu prioritas masalah kesehatan di Indonesia dan di seluruh dunia karena dalam jangka panjang peningkatan tekanan darah yang berlangsung kronik akan menyebabkan peningkatan risiko kejadian kardiovaskuler, serebrovaskuler dan renovaskuler. Pada tahun 2000, lebih dari $25 \%$ populasi dunia merupakan penderita 
hipertensi, atau sekitar 1 miliar orang, dua pertiga penderita hipertensi ada di negara berkembang (Pradana, T., 2012).

Di Indonesia masalah hipertensi cenderung meningkat. 8,3\% penduduk menderita hipertensi pada tahun 2001 dan meningkat menjadi 27,5\% pada tahun 2004. Angka prevalensi hipertensi di daerah urban pada tahun 2000 adalah 31,7\%. Sementara untuk daerah rural (Sukabumi) ditemukan prevalensi sebesar 38,7\%. Hasil SKRT 1995, 2001 dan 2004 menunjukkan penyakit kardiovaskuler merupakan penyakit nomor satu penyebab kematian di Indonesia dan sekitar 20-35\% dari kematian tersebut disebabkan oleh hipertensi (Ekowati, R., dan Sulistyowati, T., 2009).

Pemberian obat-obatan kepada pasien terkait hipertensi dilakukan secara terus menerus serta banyaknya jumlah obat yang beragam akibat komplikasi dari hipertensi dapat berpengaruh kepada kualitas hidup dari pasien. Untuk mengetahui kualitas hidup pasien yang sedang menjalani pengobatan hipertensi, kita dapat melakukan penelitian yang mengkaji pengobatan dan kualitas hidup dari pasien setelah mendapatkan obat-obatan maupun melakukan aktivitas yang dapat menjaga tekanan darah pasien (Kiki, A., dkk.,, 2007).

\section{METODE PENELITIAN}

\section{Metode Penelitian}

Metode yang digunakan ialah prospektif yaitu dengan melihat data resep dan selama 1 bulan pada pasien hipertensi. Dari hasil resep tersebut didapatkan data dari 114 pasien hipertensi.

\section{Alat dan bahan}

Alat yang digunakan adalah lembar pengumpul data dan kalkulator. Bahan yang digunakan adalah resep pasien pada kunjungan terakhir di Puskesmas Karang Asam Samarinda untuk melihat terapi obat apa saja yang telah digunakan.

\section{Pengambilan data karakteristik}

Data karakteristik pasien diambil dari resep yang didapat, data karakteristik pasien yang diambil meliputi (1) Jenis Kelamin (2) Usia, serta data karakteristik pelengkap meliputi (1) Wilayah (2) Kunjungan (3) Status Jaminan. 


\section{Pengambilan data pola pengobatan}

Data pola pengobatan pasien hipertensi yang diambil meliputi (1) Jenis Antihipertensi (2) Dosis Antipertensi (3) Frekuensi Antihipertensi, yang kemudian data disajikan dalam bentuk tabulasi.

\section{HASIL DAN PEMBAHASAN}

\section{Data Karakteristik Pasien}

Hasil tabulasi data karakteristik pasien dapat dilihat pada (Tabel 1). Dari data tersebut dapat dilihat bahwa pasien hipertensi didominasi pada jenis kelamin perempuan yaitu $(74,6 \%)$ dari 114 pasien, hal ini tidak sesuai teori bahwa seharusnya perempuan lebih kebal terhadap penyakit kardiovaskular karena dipengaruhi oleh hormon estrogen. Tetapi dari hasil data yang didapatkan tidak sesuai, hal ini berkaitan pula dengan data karakteristik usia karena mayoritas perempuan yang mengalami hipertensi tersebut adalah perempuan yang telah memasuki usia dewasa akhir hingga lansia awal yang dapat dikatakan bahwa pada usia tersebut perempuan telah memasuki masa menopause sehingga resiko terhadap hipertensi akan sama besar seperti laki-laki.

Tabel. 1 Data Karakteristik Pasien

\begin{tabular}{|c|c|c|}
\hline Karakteristik & $\begin{array}{c}\text { Jumlah } \\
\mathrm{n}(\%)\end{array}$ & $\begin{array}{l}\text { Total } \\
\mathrm{n}(\%)\end{array}$ \\
\hline Jenis Kelamin & & \multirow{3}{*}{$114(100 \%)$} \\
\hline Laki-laki & $29(25,4 \%)$ & \\
\hline Perempuan & $85(74,6 \%)$ & \\
\hline Usia & & \multirow{5}{*}{$114(100 \%)$} \\
\hline Remaja akhir (17-25) & $1(0,9 \%)$ & \\
\hline Dewasa awal (26-35) & $4(3,5 \%)$ & \\
\hline Dewasa akhir (36-45) & $38(33,3 \%)$ & \\
\hline Lansia awal (46-55) & $71(62,3 \%)$ & \\
\hline Wilayah & & \multirow{3}{*}{$114(100 \%)$} \\
\hline Dalam & $88(77,2 \%)$ & \\
\hline Luar & $26(22,8 \%)$ & \\
\hline Kunjungan & & \multirow{3}{*}{$114(100 \%)$} \\
\hline Lama & $111(97,4 \%)$ & \\
\hline Baru & $3(2,6 \%)$ & \\
\hline Status Asuransi & & \multirow{4}{*}{$114(100 \%)$} \\
\hline Jamkesda & $42(36,8 \%)$ & \\
\hline BPJS & $54(47,4 \%)$ & \\
\hline Umum & $18(15,8 \%)$ & \\
\hline
\end{tabular}


Kemudian dari data usia pasien juga dapat dilihat bahwa usia terbanyak pasien hipertensi terdapat pada lansia awal yaitu (46-55 tahun) yang dapat dikatakan bahwa pada usia tersebut telah memasuki masa degeneratif yang mempengaruhi peningkatan tekanan arterial sehinggnya menyebabkan regurgitasi aorta. Lalu untuk data wilayah untuk mengetahui bahwa pasien tersebut termasuk dalam wilayah Puskesmas tersebut atau tidak. Kemudian kunjungan merupakan data bahwa pasien tersebut merupakan pasien lama atau baru pada Puskesmas tersebut. Kemudian data status merupakan status pasien terkait jaminan kesehatannya.

\section{Data Pola Pengobatan}

Tabulasi data pola pengobatan ditunjukkan pada (Tabel 2).Pada data Jenis Antihipertensi didapatkan bahwa terapi antihipertensi yang diberikan terbanyak adalah Amlodipin yaitu 69,3\% dan merupakan terapi tunggal, Amlodipin diberikan karena merupakan first-line dari terapi hipertensi. Amlodipin merupakan antihipertensi golongan Calsium Channel Blocker (CCB) pemilihan golongan ini berkaitan dengan efek sampingnya yang rendah yang tidak mempengaruhi metabolisme tubuh serta pemilihan terapi tunggal ini karena pasien hipertensi mayoritas termasuk kedalam hipertensi stage 1.

Tabel. 2 Data Pola Pengobatan

\begin{tabular}{|c|c|c|}
\hline Terapi & $\begin{array}{c}\text { Jumlah } \\
\mathrm{n}(\%)\end{array}$ & $\begin{array}{c}\text { Total } \\
\mathrm{n}\end{array}$ \\
\hline \multicolumn{3}{|l|}{ Jenis Anti Hipertensi } \\
\hline Amlodipin & $79(69,3)$ & 114 \\
\hline Captopril & $14(12,3)$ & \\
\hline Amlodipin + Captopril & $21(18,4)$ & \\
\hline \multicolumn{3}{|l|}{ Dosis Anti Hipertensi } \\
\hline Amlodipin $5 \mathrm{mg}$ & $35(25,93)$ & 135 \\
\hline Amlodipin $10 \mathrm{mg}$ & $64(47,4)$ & \\
\hline Captopril $25 \mathrm{mg}$ & $36(26,67)$ & \\
\hline \multicolumn{3}{|l|}{ Frekuensi Anti Hipertensi } \\
\hline Amlodipin $5 \mathrm{mg} 1 \times 1$ & $36(26.67)$ & 135 \\
\hline Amlodipin $10 \mathrm{mg} 1 \times 1$ & $61(45,2)$ & \\
\hline Amlodipin $10 \mathrm{mg} 1 / 2 \times 1$ & $5(3,7)$ & \\
\hline Captopril $25 \mathrm{mg} 2 \times 1$ & $33(24,4)$ & \\
\hline
\end{tabular}

Kemudian diberikan antihipertensi golongan Angiotensin Converting Enziminhibitor (ACE-i) yaitu Captopril (12,3\%). Pemberian Captopril karena efek sampingnya yang aman terhadap beberapa pasien yang memiliki penyakit penyerta gagal jantung. Kedua golongan ini merupakan first-line sehingga pemilihannya tidak masalah pada pasien 
hipertensi stage 1 dengan mempertimbangkan beberapa penyakit penyerta maupun efek samping dari obat tersebut. Kemudian didapatkan data terapi kombinasi dari Amlodipin dan Captopril, terapi kombinasi ini diberikan kepada pasien hipertensi stage 2 yang telah mengkonsumsi terapi tunggal tetapi tidak memberikan efek penurunan tekanan darah yang signifikan. Diketahui pula terapi kombinasi dari Amlodipin dan captopril merupakan kombinasi yang umum serta memiliki efek penurunan tekanan darah yang baik.

Data dosis Antihipertensi menunjukkan bahwa penggunaan Amlodipin $10 \mathrm{mg}$ merupakan data terbanyak hal ini menunjukkan bahwa mayoritas pasien merupakan pasien dengan hipertensi stage 1 yang sedang menjalani terapi antihipertensi ini. Sedangkan untuk Amlodipine $5 \mathrm{mg}$ diberikan kepada pasien hipertensi yang baru saja divonis memiliki penyakit hipertensi. Tidak menutup kemungkinan kedepannya pasien tersebut akan diberikan peningkatan dosis menjadi $10 \mathrm{mg}$ ketika penurunan tekanan darahnya tidak memberikan hasil yang maksimal dengan dosis Amlodipine 5 mg. Kemudian Captopril 25 mg merupakan dosis lazim yang diberikan kepada pasien hipertensi stage 1 .

Data Frekuensi Antihipertensi yang terdapat pada (Tabel 2) bahwa Amlodipin 5 mg diberikan $1 \times 1$ yang merupakan frekuensi lazim dan sudah mengikuti tatalaksana yang ada, begitupun dengan Amlodipin $10 \mathrm{mg} 1 \times 1$. Tetapi ada beberapa pasien yang diberikan Amlodipin $10 \mathrm{mg} 1 / 2 \times 1$, dari tatalaksana yang ada tidak dapat menjelaskan hal tersebut, tetapi hal ini berkaitan dengan ketersediaan stok obat pada Puskesmas tersebut, yang dapat dikatakan bahwa dosis yang diperlukan sebenarnya $5 \mathrm{mg}$ tetapi karena ketersediaan stok maka diberikan $10 \mathrm{mg} 1 / 2 \times 1$ kepada pasien tersebut. Lalu Captopril $25 \mathrm{mg} 2 \times 1$ merupakan frekuensi yang sudah tepat dan sesuai dengan tatalaksana.

\section{KESIMPULAN}

Pasien didominasi oleh wanita dengan tingkat usia rata-rata 46-55 tahun. Pemberian terapi tunggal Amlodipin 69,3\% dan Captopril 12,3\% dan terapi kombinasi Amlodipin dan Captopril 18,42\%. Dosis antihipertensi yang digunakan Amlodipin $5 \mathrm{mg}$ 25,9\%, Amlodipin $10 \mathrm{mg}$ 47,4\% dan Captopril 25 mg 26,6\%.

\section{DAFTAR PUSTAKA}

Dipiro, J. T., Wells, B. G., Schwinghammer, T. L., dan Dipiro, C. V., 2009. Pharmacotherapy Handbook. McGraw-Hill. New York.

Ekowati, R., dan Sulistyowati, T., 2009. Prevalensi Hipertensi dan Determinannya di Indonesia. Majalah Kedokteran Indonesia. 59. (12). 
Kiki, A., Harmani, K., dan Basuni, R., 2007. Quality of Life Evaluation After Coronary Artery Bypass Graft Surgery in Patient who Underwent Phase III Rehabilitation Program. Jurnal Kardiologi Indonesia. 28. 198-196.

Lumbantobing, 2008. Tekanan Darah Tinggi. FKUI. Jakarta. 